\title{
The long winding road to the safer glucocorticoid receptor (GR) targeting therapies
}

\author{
Ekaterina A. Lesovaya ${ }^{1,2}$, Daria Chudakova ${ }^{3}$, Gleb Baida ${ }^{3}$, Ekaterina M. Zhidkova ${ }^{1}$, \\ Kirill I. Kirsanov ${ }^{1,4}$, Marianna G. Yakubovskaya ${ }^{1}$ and Irina V. Budunova ${ }^{3}$ \\ ${ }^{1}$ Deparment of Chemical Carcinogenesis, Institute of Carcinogenesis, N.N. Blokhin NMRCO, Moscow, Russia \\ ${ }^{2}$ Department of Oncology, I.P. Pavlov Ryazan State Medical University, Ryazan, Russia \\ ${ }^{3}$ Department of Dermatology, Northwestern University, Chicago, IL, USA \\ ${ }^{4}$ Deparment of General Medical Practice, RUDN University, Moscow, Russia \\ Correspondence to: Ekaterina A. Lesovaya, email: lesovenok@yandex.ru \\ Keywords: glucocorticoid receptor; glucocorticoids; SEGRAM; REDD 1; drug repurposing \\ Received: December 13,2021 Accepted: January 25, $2022 \quad$ Published: February 18, 2022
}

Copyright: ๑ 2022 Lesovaya et al. This is an open access article distributed under the terms of the Creative Commons Attribution License (CC BY 3.0), which permits unrestricted use, distribution, and reproduction in any medium, provided the original author and source are credited.

\section{ABSTRACT}

Glucocorticoids (Gcs) are widely used to treat inflammatory diseases and hematological malignancies, and despite the introduction of novel anti-inflammatory and anti-cancer biologics, the use of inexpensive and effective Gcs is expected to grow. Unfortunately, chronic treatment with Gcs results in multiple atrophic and metabolic side effects. Thus, the search for safer glucocorticoid receptor (GR)-targeted therapies that preserve therapeutic potential of Gcs but result in fewer adverse effects remains highly relevant. Development of selective GR agonists/modulators (SEGRAM) with reduced side effects, based on the concept of dissociation of GR transactivation and transrepression functions, resulted in limited success, and currently focus has shifted towards partial GR agonists. Additional approach is the identification and inhibition of genes associated with Gcs specific side effects. Others and we recently identified GR target genes REDD1 and FKBP51 as key mediators of Gcs-induced atrophy, and selected and validated candidate molecules for REDD1 blockage including PI3K/Akt/ mTOR inhibitors. In this review, we summarized classic and contemporary approaches to safer GR-mediated therapies including unique concept of Gcs combination with REDD1 inhibitors. We discussed protective effects of REDD1 inhibitors against Gcsinduced atrophy in skin and bone and underlined the translational potential of this combination for further development of safer and effective Gcs-based therapies.

\section{INTRODUCTION}

Glucocorticoids (Gcs) are among the most frequently used anti-inflammatory and anti-lymphoma drugs. Synthetic Gcs were first introduced into clinical practice in 50-s, and since then, more than 30 Gcs were approved for systemic and topical use. Despite the recent successful development of novel immunosuppressive and anti-cancer drugs and novel biologics targeting specific disease-related signaling pathways, very effective and inexpensive Gcs remain widely used. Overall, the global Gcs market was $\sim \$ 4.5$ billion in 2020 with the topical Gcs as a dominant segment, and it is expected that market will continue to steadily grow. The biological effects of
Gcs are mediated by the glucocorticoid receptor (GR), a transcription factor that regulates the expression of thousands of target genes, and plays an important role in the regulation of glucose, lipid and protein metabolism, stress response, cell proliferation and apoptosis, and inflammation. Unfortunately, chronic treatment with Gcs results in multiple metabolic, atrophic and other adverse effects that became apparent starting from their early use. The increased understanding of GR molecular biology and the mechanisms underlying therapeutic and side effects of Gcs, powered a tremendous effort of pharmaceutical companies and academia directed toward the development of safer GR-targeted therapies. In this review, we discuss modern understanding of molecular peculiarities of GR 
function providing different approaches to these safer therapies including the search for alternative (frequently non-steroidal) GR ligands with preserved therapeutic activities but reduced side effects; and the search for "tissue protectors" (based on the drug repurposing of FDA-approved and experimental drugs) to use in combination with Gcs.

\section{Effects of glucocorticoids are mediated by the glucocorticoid receptor}

Gcs are steroid hormones mostly generated in the adrenal cortex, even though some are synthesized locally from precursors from cholesterol metabolites such as pregnenole by different enzymes including CYP11A1 $[1,2]$. The major natural glucocorticoid in humans is cortisol; it is converted from inert precursor cortisone by $11 \beta$-hydroxysteroid dehydrogenase type 1 (11ßHSD1). The reverse conversion from biologically active cortisol to non-active cortisone is mediated by $11 \beta \mathrm{HSD} 2$.

Key functions of Gcs include regulation of glucose, protein and lipid metabolism, cell proliferation and differentiation, development, stress response, apoptosis, immune response and inflammation $[3,4]$.

Gcs exert their effects via the glucocorticoid receptor (GR, NR3C1), a well-known transcription factor (TF) from the superfamily of nuclear hormone receptors $[3,5]$. In inactive conformation it resides in the cytoplasm bound to the molecular chaperones - heat shock proteins and immunophilins [4]. Upon stimulation by Gcs, GR undergoes phosphorylation, homodimerization, and translocates to the nucleus. Activation of gene expression (transactivation, TA) requires GR homodimer binding to the palindromic Gc responsive elements (GRE) in gene promoters. Negative gene expression regulation (transrepression, TR) is mediated via diverse mechanisms including binding of GR to less conserved negative GREs or by binding of GR monomer to other TFs including proinflammatory NF-kB, AP-1, IRF, (interferon-regulated factors), STATs, thus blocking their activity [6-9].

It has been well accepted in the field that TR is an important mechanism underlying therapeutic antiinflammatory and anti-lymphoma effects of Gcs [10]. At the same time, mediated by GR homodimer TA regulates GR signaling linked to gluconeogenesis, lipid and protein catabolism, and often mediates the development of atrophic effects in different tissues (such as skin and muscle atrophy) as well as some metabolic adverse effects (hyperglycemia, steroid-induced diabetes) [7, 11-13].

\section{Glucocorticoids as therapeutic agents}

Isolation and crystallization of natural Ges in 1920-1930s led to the successful synthesis of cortisone in 1947 [14]. In 1948 the first patient with rheumatoid arthritis was treated with cortisone, and in
1952 hydrocortisone was used for the first time to treat atopic dermatitis. Since then, more than 30 Gcs were approved for systemic and topical clinical use, including betamethasone, budesonide, cortisone, dexamethasone (Dex), hydrocortisone, methylprednisolone, prednisolone, prednisone, triamcinolone. Their wide use in clinical practice is based on their strong anti-inflammatory activity and anti-proliferative/pro-apoptotic effects important for anti-cancer activity. Indeed, Gcs inhibit expression of a large set of inflammatory cytokines and chemokines IL-1, IL-2, IL-12, IL-18, TNF- $\alpha$, INF- $\gamma$, GM-CSF, and others, as well as central regulators of cell cycle - Cyclins and CDKs, $[6,14,15]$.

Despite a recent successful development of novel anti-inflammatory and anti-cancer therapies targeting specific cytokines and growth factors/pathways, the inexpensive and very efficient Gcs are still widely used for the treatment of millions of patients with allergies, chronic inflammatory and autoimmune diseases such as asthma, rheumatoid arthritis (RA), ulcerative colitis/ Crohn disease, multiple sclerosis, inflammatory and hyperproliferative skin diseases including atopic dermatitis and psoriasis, different skin rashes, itches [3, $16,17]$. Gcs are also extensively used for the treatment of different forms of ocular inflammation, macular edema, and macular degeneration and due to their antiangiogenic properties for prevention of neovascularization in the eye $[3,18-21]$. In addition, they are also an important part of the postoperative patient management and immunosuppressive combination therapies in organ transplant recipients.

Gcs have been an effective component of antilymphoma therapies due to their anti-proliferative, proapoptotic and anti-angiogenic activities [22]. Synthetic Gcs, such as Dex, are routinely included in chemotherapy protocols of acute lymphoblastic leukemia, chronic lymphocytic leukemia, multiple myeloma, Hodgkin's and non-Hodgkin's lymphoma [23].

In case of epithelial cancers, Gcs are mostly used as a palliative therapy to reduce the adverse effects of chemotherapy: to increase appetite, decrease nausea (for some chemotherapeutic regimens that include cisplatin, Gcs are first-line antiemetics), weight loss, reduce fatigue, severe skin rashes typical for EGF and folate inhibitors. Ges are also applied in abatement of pain associated with bone metastasis by inhibiting the secretion of prostaglandins [24]. Even more, Gcs provided modest therapeutic benefit in early stage prostate cancer and demonstrated potential for use in ER-positive breast cancers due to GR inhibition of E2-mediated cell proliferation [25-28].

Currently Gcs market was estimated for more than $\$ 4$ billion with the predomination of topical Gcs, which represent up to $60-80 \%$ of total dermatological and ophthalmological products sold [29]. It is expected that market will continue to grow by $\sim 3.5-4 \%$ yearly due to 
the increasing incidence of chronic diseases and growing geriatric population preferentially treated with Gcs for inflammatory diseases [30].

\section{Major metabolic and atrophic adverse effects of glucocorticoids}

Despite well-known Gcs efficacy as antiinflammatory and anti-lymphoma drugs, chronic treatment is hampered by multiple adverse effects, most of which became apparent starting from early use of Gcs in 60-s. The list of Gc-induced adverse effects includes the whole spectra of complications: from hypertension and cardiovascular complications (including increased coagulation and vein thrombosis), glaucoma, metabolic and atrophic complications to cognitive and mood disorders [3, 22, 31-38].

\section{Metabolic syndrome: Gc-induced hyperglycemia,} insulin resistance, diabetes and fat metabolism

One of the fundamental physiological functions of Gcs is to oppose the effects of insulin and enhance the liver production of glucose [22, 34, 35]. Gcs decrease rate-limiting insulin receptor signaling molecules and reduce insulin-mediated increase in blood flow to muscles, simultaneously promoting gluconeogenesis in the liver via upregulation of enzymes tyrosine aminotransferase (TAT), glucose-6-phosphatase (G6P) and phosphoenolpyruvate carboxykinase (PEPCK) [22, 34, 39]. Activation of these mechanisms lead to a deregulated carbohydrate metabolism, hyperglycemia, and in more severe cases to steroid-induced diabetes. Ges also control lipid metabolism, preadipocyte maturation, and distribution and accumulation of fat in different fat depots [40-45]. Chronic treatment with Gcs results in fat redistribution, truncal (central) and visceral obesity accompanied by macrophage infiltration and ectopic lipid accumulation in liver and skeletal muscle, all of them associated with insulin resistance and cardiovascular disease [43].

\section{Gc-induced osteoporosis}

Chronic treatment with Gcs increase the risk of osteopenia, osteoporosis and aseptic osteonecrosis [36, 46]. Gcs decrease bone formation via inhibiting osteoblast proliferation and differentiation, reducing bone matrix protein synthesis in osteoblasts and increasing bone resorption via activating osteoclasts [46]. Mechanistically, both GR-mediated TA and TR are involved in Gc-induced osteoporosis. Gcs simultaneously stimulate the expression of RANKL (TNFSF11), a key factor for osteoclast differentiation/activation inhibiting osteoclast apoptosis, and reduce the expression of OPG (osteoprotegerin, TNFRSF11B), which promotes osteoclast apoptosis $[46,47]$. Thus, Gcs increase RANKL/OPG ratio in bone, leading to osteoporosis. In addition, Gcs repress the expression of osteocalcin (OC), a key component of bone matrix produced by osteoblasts $[48,49]$. Ges also increase osteoclast activity by decreasing gastrointestinal $\mathrm{Ca} 2+$ absorption and increasing urinary $\mathrm{Ca} 2+$ excretion, which triggers an additional osteoclast-mediated bone resorption [46].

\section{Gc-induced muscle waste}

Glucocorticoids disrupt muscle homeostasis in multiple ways, by increasing catabolism, induction of ubiquitin-proteasomal pathway leading to proteolysis via transcriptional activation of E3 ligases atrogin-1 and MuRF1 [38]. The Gcs-mediated inhibition of IGF-1/ $\mathrm{PI} 3 \mathrm{~K} / \mathrm{Akt}$ pathway, the myostatin signaling and the NF-kB signaling also leads to inhibition of protein synthesis and to protein degradation [50]. In addition, glucocorticoids negatively affect muscle anabolism by inhibiting amino acid transport into muscles. mTOR, its inhibitor REDD1/ DDIT4 and transcription factor KLF15 are involved in glucocorticoid-mediated repression of protein synthesis $[50,51]$. In parallel, Gcs attenuate myogenic cell proliferation and differentiation, and reduce muscle mass [38].

\section{Gc-mediated skin atrophy}

Gc-induced skin atrophy is one of the most frequent side effects of topical and also systemic Gcs. It is characterized by a dramatic loss in skin thickness, increased fragility, tearing, bruising, permanent stretch marks (striae), and compromised skin barrier function along with delayed wound healing, followed by the increased risk for developing of secondary wounds and infections at the affected site [12, 52-55]. Gcs induce changes in all skin compartments, and appendages such as hair follicles and sebaceous glands. Typical changes in epidermis are hypoplasia, decreased number and size of keratinocytes, diminished stratum corneum. In dermis Ges inhibit fibroblast proliferation, decrease collagen, elastin and other ECM proteins synthesis, reduce production of hyaluronic acid. Gcs also induce drastic atrophy of dermal adipose in mice after topical application and in patients after intradermal injections [56]. As discussed below, there are some parallels between mechanisms involved in skin atrophy and muscle waste, as the blockage of pro-proliferative anabolic mTOR/Akt signaling by Gcs plays central role in both skin and muscle steroid atrophy $[37,57]$.

\section{Approaches for the development of safer GR- targeted therapies}

\section{Modified classical glucocorticoids}

Side effects associated with chronic high dose Gcs regimens made the search for safer GR-targeted therapies inevitable $[58,59]$. Initially, the focus was on the modifications of the classical Gcs: delayed-release prednisone [60], fluticasone and budesonide with the specificity to lung tissues [58], targeted liposomal Gcs 
[61], nitrosteroids with the release of the low-dose nitric oxide and milder side effects than their parent compound prednisone [62], non-halogenated double-ester-type Gcs prednicarbate and 6-methyl-prednisolone aceponate that have reduced atrophogenic activity compared to conventional steroids. Another example is so-called soft drug approach by delivering Gcs that are active only at the site of action (e.g., in the lung or eye) but undergo a one-step predicted metabolism reducing the systemic exposure and limiting systemic side effects. Loteprednol etabonate and Ciclesonide have demonstrated efficacy and increased safety for the treatment of ophthalmic disorders and asthma respectively [63].

\section{Development of dissociating selective GR activators/ modulators (SEGRAM)}

Alternative direction was the search for “dissociating" GR activators with improved therapeutic index. It started in late 1990s and was based on the concept of "dissociation" of GR TR and TA functions via ligands that do not activate GR dimerization and GR dimermediated TA linked to many atrophic and some metabolic adverse effects. A large number of research groups at pharmaceutical companies and academic institutions used both targeted synthesis of dissociating GR ligands and screening of chemical libraries to search for GR modulators that are currently called SEGRAM (selective GR agonists/modulators). Major tests used for detection and evaluation of TA and TR induced by SEGRAM as well as for evaluation of integral effects on inflammation and glucocorticoid-dependent side effects include in vitro molecular profiling of TR- and TA-associated genes, luciferase reporter assays - activation of GRE.Luciferase (for TA) and inhibition of NF-kB.Luciferase (for TR). The in vitro analysis is usually followed by the analysis of antiinflammatory, metabolic, and atrophic effects in vivo (by ear edema and paw swelling assays, metabolic glucose test, Gcs-induced osteoporosis, skin atrophy and muscle waste models).

The first successful attempt at testing the activation/ repression hypothesis was reported by Vayssiere et al. in 1997: the authors described several SEGRAM that separated in vitro TA and TR GR functions (RU24858, RU40066, and RU24782) [64]. Next generation of SEGRAM, compounds ZK245186 (Mapracorat/BOL-303242-X) and AL-438, demonstrated the affinity to GR close to Dex, the inhibition of the expression of inflammatory cytokines IL-1, IL-2, IL-8, prostaglandin-E2 and E-selectin as well as the antiinflammatory therapeutic activity in vivo but exhibiting less undesirable effects than synthetic Gcs [54, 65-67]. Other synthetic SEGRAMs, compounds CpdX and CpdX-D3 related to Mapracorat, also demonstrated promising results in in vivo studies $[68,69]$.

SEGRAM PF-04171327 (Fosdagrocorat made by Pfizer) was in clinical trials for the treatment of rheumatoid arthritis $[70,71]$. Fosdagrocorat showed higher therapeutic activity together with reduced side effects such as alteration of glucose metabolism and inhibition of bone formation [70, 71]. A number of potent, nonsteroidal, selective indazole ether based SEGRAM was developed by AstraZeneca for the inhaled treatment of respiratory diseases. AZD5423, AZD7594 and AZD9567 with high affinity to GR were in clinical trials for the therapy of chronic obstructive pulmonary disease (COPD) [72-74], asthma $[75,76]$ and rheumatoid arthritis [77], respectively. ZK216348 is a nonsteroidal SEGRAM with interesting properties which induces potent anti-inflammatory effects, but its capacity to transactivate is weaker compared to standard glucocorticoids $[78,79]$. It was demonstrated that SEGRAM GSK866 by GlaxoSmithKline and its analogues with cysteine reactive warheads revealed stronger antiinflammatory potential with less side effects in cutaneous and ocular inflammatory diseases, which is promising area for therapeutic intervention [80]. An interesting SEGRAM for topical use, LEO 134310 (LEO Pharma), is in clinical trials for psoriasis. It demonstrated minimal atrophic effects in skin and minimal systemic side effects as it was designed as a "dual-soft" GR ligand rapidly metabolized in liver and blood [81].

\section{Natural compounds with SEGRAM properties}

There have been extensive efforts to search for natural compounds (or their synthetic analogs) with SEGRAM properties, especially among the plant metabolites including terpens, terpenoids, polyphenols, and alkaloids that represent a rich source of bioactive compounds with beneficial health effects. Terpenes are the largest class of natural small-molecule metabolites mostly produced by conifers; they have poly-isoprene structure biosynthesized by condensation and modification of several isoprene $\left(\mathrm{C}_{5} \mathrm{H}_{8}\right)$ units [82]. The sub-class of terpens are terpenoids that contain additional functional chemical groups and include well-known and widely used in traditional medicine cannabinoids, ginkolide and biobalide found in Ginko biloba, curcuminoids, ginsenosides found in Panax ginseng, and others. Notably, isoprenoid pathways are common for biosynthesis of steroids, including Gcs, and their major precursor cholesterol [83].

Importantly, some of plant secondary metabolites have typical steroid structure, and can bind various steroid hormone receptors [84]. They can act as agonists, antagonists, or modulators, and some can affect steroid metabolism, resulting in biological effects through altered endogenous steroid concentrations [84].

Significant number of plant-derived biomolecules have demonstrated capability to affect GR function which is usually assessed using cells expressing high levels of GR (for example, A549 cell line) and readout assays allowing for evaluation of GR TA/TR activity (for example, GRE. Luciferase and NF-kB.Luciferase reporter-based assays) $[85,86]$. In some cases, more thorough investigations included analysis of effects on GR expression, major 
steps in GR activation: its phosphorylation (mostly at activating Ser211) and nuclear translocation; and GR ligand properties assessed by molecular docking or ligand-binding assays [87-94]. Recently, focused screens for natural mimetics of cortisol were performed utilizing genetically engineered sensor cells detecting GR nuclear translocation, which demonstrated that decursin from Dong quai (Angelica sinensis, commonly known as female ginseng), and L-limonene from peppermint oil induce GR translocation similar to cortisol $[95,96]$.

In addition, some other terpenes/terpenoids (astragaloside IV, avicin $\mathrm{D}$, ginsenosides Re, Rg1 and compound $\mathrm{K}$; boswellic acids, $\beta$-iscin; $\beta$-ionone) and other plant metabolites (berberine, extract from Salsola komarovii) were able to bind to GR. Moreover, many plant compounds including sstragaloside IV, avicin D, boswellic acids, berberine were able to induce significant nuclear translocation of GR ([85, 97-99] and Supplementary Table 1). However, in most cases these plant metabolites were not able to induce GR transactivation, and some compounds and plant extracts (curcumin, 4-hydroxyderricin and xanthoangelol, Peony Rubra Radix extract) inhibited GR TA ([100-102] and Supplementary Table 1). The exceptions are astragaloside IV, baicalein and endiandrin A that were able to activate GR-dependent genes/GRE. Luciferase reporter under certain experimental conditions [87, 97, 103].

At the same time, many discussed above compounds demonstrated SEGRAM or dissociating GR ligand activity. For example, boswellic acids suppressed GR TA and induced NF-kB TR via GR [98]; $\alpha$-boswellic acid selectively inhibited CBG/Corticosteroid-binding globulin gene (marker for GR TR), but did not induce TAT/Tyrosine aminotransferase expression (key enzyme for glucocneogenesis and a marker for GR TA) [97]. Ginsenoside compound Rg1 and avicin D have also demonstrated GR TR but not TA activity [104].

The SEGRAM activity of these biomolecules was assessed not only in human cell lines, but in some cases in vivo in zebrafish larvae model and in rodents ([87, 95, 98, 100, 102-106] and [99, 101, 107, 108], respectively).

Many of these natural compounds with SEGRAM properties have anti-inflammatory, antimicrobial, and anti-cancer activity $[85,109,110]$, and several SEGRAMs listed above are active components of traditional medicinal herbs. For example, preparations from woody vines rich in boswellic acids are used in China to treat rheumatoid arthritis and inflammation; decursin is a component of Dong quai, traditional Chinese medicinal herb; Ginseng is the traditional medicinal herb and one of the top-selling herbal supplement worldwide [111]). However, the clinical use of many other compounds is limited because of narrow therapeutic window and diverse toxic effects (triptolide [108, 112]), or low bioavailability (astragaloside IV [113]).

One of the interesting examples of synthetic analogs of natural SEGRAM is Compound A (CpdA), a stable analog of the hydroxyphenyl aziridine precursor found in the Namibian shrub Salsola tuberculatiformis Botschantzev [5]. Others and we showed that CpdA has high affinity to GR. In different cell types CpdA induced modest GR nuclear translocation but did not induce GR dimerization and GR phosphorylation at Ser211, critical for GR TA activity [5]. Consequently, CpdA did not significantly affect or even inhibited constitutive and Gcsinduced activation of endogenous genes. In contrast, CpdA and classical Gcs have remarkably similar TR profiles, suppressing the activity of many pro-proliferative and anti-apoptotic TFs including NF- $\kappa$ B, AP-1, Ets-1, Elk1, SRF, NFATc [114]. Importantly, CpdA demonstrated strong anti-inflammatory activity in multiple models of inflammatory diseases (collagen-induced arthritis, experimental autoimmune neuritis and encephalomyelitis, type 1 diabetes, Th2-driven mouse asthma model), as well as strong anti-cancer effects with minimal adverse effects as measured by glucose metabolism and skin atrophy [7, 11, 115-122].

\section{Shift of paradigm: from dissociating GR ligands to partial GR agonists}

Overall, during last 20 years the major efforts by pharmaceutical companies and academia to make GR-targeted therapies safer have been focused on the development of GR agonists/modulators (SEGRAM) that can dissociate TR and TA GR functions. However, despite of some progress, and many interesting findings related to both synthetic and natural compounds, especially in in vitro studies and in some animal models, the attempts to generate/discover truly dissociating GR ligands/modulators had limited success, and only few SEGRAMs have reached clinical trials. Moreover, even leading SEGRAMs such as Fosdagrocorat (Pfizer) developed for the treatment of rheumatoid arthritis and Mapracorat that was in clinical trials for atopic dermatitis (Bayer) and ocular allergic conjunctivitis (by Bausch \& Lomb) have never been marketed, and their further development was put on hold by the companies. Similarly, none of the natural compounds with SEGRAM properties that have been used in traditional medicine for a long time, have been approved as prescription drugs, and they are sold currently only as dietary supplements.

The difficulties with SEGRAM development reflect the significant limitations of the TR/TA dissociation concept, first of all because the analysis of Gcs molecular signatures in different tissues including liver, brain, skin revealed that side effects as well as full therapeutic activity of Ges require both TA and TR [123]. For example, Gcs upregulate anti-inflammatory genes glucocorticoid-induced leucine zipper (GILZ) and dual specificity phosphatase (DUSP1), and cell cycle inhibitors p21 and p27 [124-126]. On the other hand, Gcs inhibit OPG (osteoprotegerin), one of the key anti- 
osteoporotic genes in bone [7, 12, 123, 127, 128]. In case of osteoporosis, up-regulation of proapoptotic genes contributes to Gc-induced apoptosis in osteocytes, and inhibition of OPG together with RANKL up-regulation lead to enhanced osteoclastogenesis [129]. Up-regulation of Plasminogen Activator Inhibitor 1 (PAI-1) by Ges in the patients with inflammation increased the risk of venous thromboembolism via inhibition of the breakdown of blood clots [130, 131].

The other problems with the search/design of SEGRAM are the lack of three-dimensional structures of full-length GR that preclude efficient molecular modeling and docking studies; need of assays with high predictive power for screening of SEGRAM anti-inflammatory and specific adverse effects in human cells in vitro; the lack of translatability from animal models to human patients [123].

Currently, the approach for SEGRAM design shifted from dissociating GR ligands towards GR partial agonists following the strategy successfully used for the development of selective ER modulators (SERMs). Partial non-steroidal GR agonists AZD7495 and AZD9567 developed by AstraZeneca retained full capability to induce GR TR (assessed by inhibition of LPS induced $\mathrm{TNF} \alpha$ release in human blood cells), but did not activate specific genes involved in osteoporosis (induction of osteoprotegerin, OPG, in human osteoblasts) and glucose metabolism (assessed in human hepatocytes by activation of tyrosine aminotransferase, TAT). AZD9567 demonstrated excellent anti-inflammatory activity in animal experiments, and is currently in clinical trials for rheumatoid arthritis and type 2 diabetes in comparison with prednisolone [77].

\section{Combination therapy approach to increase therapeutic index of Glucocorticoids}

As discussed above, it became increasingly clear that it is nearly impossible to design/select truly dissociating GR ligands that can reduce multiple side effects while retaining the therapeutic activity of classical Gcs. Much more feasible strategy for safer GR-targeted therapies is to focus on the alleviation of specific side effects taking into consideration cell/tissue-specific GR/ Gcs molecular signatures. The examples below illustrate the successful attempts (both empirical and via multi-step screening) to increase the therapeutic index of Gcs using combination of Ges with some other drugs.

\section{Combinational therapies to increase therapeutic effects of Ges}

Glucocorticoid monotherapy is adequate for some inflammatory diseases, which require low-dose treatments. However, for more severe inflammatory and autoimmune disorders as well as blood cancer, Gcs are combined with other drugs.
Interestingly, some combination therapies increased therapeutic effects of Gcs without exacerbation of their adverse effects. For example, combination of prednisolone with anti-thrombotic drug dipyridamole resulted in an increased anti-inflammatory effect of prednisolone through selective amplification of Gcs-mediated antiinflammatory signaling [132]. Another recent work demonstrated that GR binding to GREs in $\beta$-arrestin 1 and 2 and modulates their expression and alters G-protein coupled receptor (GPCR) signaling which may have beneficial implications in combination therapy using corticosteroids and GPCR-based drugs in the treatment of asthma and COPD [133]. Further, it was discovered that rapamycin sensitized multiple myeloma, leukemia and lymphoma cells to Dex-induced apoptosis, increasing its anti-lymphoma effects $[134,135]$. Unfortunately the promising approach to induce "dissociation" of GR TR from TA, and to increase therapeutic Ges index by using Dex together with SEGRAM CpdA, failed [136].

\section{Combinational therapies to decrease atrophic effects of Ges}

There are also findings (sometime by serendipity, but frequently by design) related to the decrease of atrophic and metabolic adverse effects when Gcs were combined with other drugs. For example, it was shown that glycyrrhizic acid from Licorice root, dipyridamole (mentioned above), and parathyroid hormone (PTH) were able to attenuate the effects of Gcs on bone loss in rodents $[1,108,117,118]$. Japanese studies demonstrated that branched amino acids have protective effect against steroid-induced muscle dystrophy in animal models and also in patients with rheumatic disorders due to the blockage of catabolic processes in muscle [119, 123].

There are also important findings related to the combination of Gcs with other steroid receptor/nuclear receptor ligands. Vitamin $\mathrm{D}_{3}$ and its analogues diminish anti-atrophic effects of glucocorticoids in muscle and bone [137-141]. As there is an overlap in enzymatic cascades involved in the synthesis of Gcs and Vitamin $\mathrm{D}_{3}$, some Vitamin D metabolites could also act as potential modulators of GR activity via effects on Ges synthesis/ metabolism [142-144].

It is known that Ges bind not only GR but also mineralocorticoid receptor (MR), and that inhibitors of $\mathrm{MR}$, such as spironolactone are considered for cotreatment with glucocorticoids to reduce some adverse effects, such as skin atrophy [145]. The inhibitors of $11 \beta \mathrm{HSD} 1$ that plays a key role in regulation of glucocorticoids in tissues, were also considered for the reduction of glucocorticoid side effects (for example, Glycyrrhetinic acid, KR-67607, AZD4017) [146-149].

\section{Search for tissue protectors to spare tissues from steroid atrophy}

The strategically different systematic approach for combining of Gcs with tissue protectors requires 
Table 1: Effects of PI3K/Akt/mTOR inhibitors on REDD1 basal and inducible expression in HaCaT keratinocytes

\begin{tabular}{|c|c|c|c|c|c|c|c|}
\hline \multirow{2}{*}{$\frac{\text { Compound }}{\text { Rapamycin }}$} & \multirow{2}{*}{$\frac{\text { Major Targets }}{\text { mTORC1 }}$} & \multicolumn{2}{|c|}{$\begin{array}{l}\text { REDD1 basal } \\
\text { RNA/protein }\end{array}$} & \multicolumn{2}{|c|}{$\begin{array}{l}\text { REDD1 Gc-induced } \\
\text { RNA/protein }\end{array}$} & \multicolumn{2}{|c|}{$\begin{array}{l}\text { FKBP51 induced } \\
\text { RNA/protein }\end{array}$} \\
\hline & & + & + & + & + & + & + \\
\hline OSI-027 & $\mathrm{mTORC} 1 / 2$ & + & + & + & + & $\mathrm{N} / \mathrm{A}$ & N/A \\
\hline Wortmannin & PI3K & + & + & + & + & + & + \\
\hline LY-294002 & PI3K & + & + & + & + & + & + \\
\hline NVP-BEZ235 & $\mathrm{PI} 3 \mathrm{~K} / \mathrm{mTOR}$ & $\mathrm{N} / \mathrm{A}$ & + & $\mathrm{N} / \mathrm{A}$ & + & + & + \\
\hline AZD8055 & $\mathrm{PI} 3 \mathrm{~K} / \mathrm{mTOR}$ & + & + & + & + & + & + \\
\hline MK-2206 & Akt1/2/3 & $\mathrm{N} / \mathrm{A}$ & + & $\mathrm{N} / \mathrm{A}$ & + & + & + \\
\hline
\end{tabular}

HaCaT keratinocytes were pretreated with REDD1 inhibitors (1-10 uM) for hrs, and treated with FA (1 uM) for 6-24 hrs. The expression of REDD1 was determined by Western blotting and Q-PCR and normalized to Rpl27 expression. References: $[150,154]$. Abbreviation: N/A: not assessed.

the identification of the Gcs-induced genes causatively implicated in specific Gcs adverse effects followed by targeted inhibition of their expression. We validated this approach, using skin atrophy as a model, via analysis of GR molecular signature in skin, identification and validation of potential atrophogenes and search (via repurposing approach) for small molecule drugs that could inhibit atrophogene expression in steroid-treated skin. Later this approach was extended towards osteoporosis model. We used the model of Gc-induced osteoporosis in mice and demonstrated the potency of PI3K/Akt/mTOR modulators to diminish bone resorption induced by Dex [150].

\section{Identification of key atrophogenes involved in atrophic effects of glucocorticoids}

Bioinformatics analysis of GR target genes upregulated both in human and mouse skin topically treated by Gcs, revealed several dozens of common upregulated differentially expressed genes (DEGs, GEO accession numbers: GSE120783, GSE59151 [35, 42]). Several of these DEGs appeared to be negative regulators of major anabolic mTOR/Akt signaling pathway, including REDD1 (regulated in development and DNA damage 1)/DDIT4 (DNA damage induced transcript 4) and FKBP5 (FK506-binding protein 51) [42, 61]. Both of these genes are GR targets [151-154]. The major function of REDD1 is negative regulation of mTORC1, while FKBP51 serves as a molecular chaperone for multiple clients. However, they both play the important role in negative regulation of $\mathrm{mTOR} / \mathrm{Akt}$ signaling via control of Akt dephosphorylation: FKBP51 -at Ser473 [155], and REDD1 -at Thr308 [156].

We demonstrated that REDD1 and FKBP51 indeed act as atrophogenes in skin. Both REDD1 knockout (KO) and FKBP5 KO animals were more resistant to Gcsinduced skin hypoplasia than wild type mice: the lack of REDD1 or FKBP51 expression safeguarded all skin compartments (epidermis, dermis and dermal adipose) and protected CD34+ follicular epithelial stem cells from negative steroid effects $[42,61]$.

REDD1 role in the regulation of muscle metabolism and shift of protein synthesis/degradation balance towards catabolism during treatment with Ges is well recognized [123]. Moreover, the finding that REDD1 KO animals appeared to be more resistant to Gcs-induced muscle waste provided direct experimental evidence that REDD1 plays also a causative role in steroid-induced muscle atrophy [56]. The role of FKBP51 in muscle atrophy remains to be investigated.

\section{GR and PI3K/Akt/mTOR crosstalk is involved in glucocorticoid-induced atrophy in skin and bone}

The computational screening of LINCS database of 20,000 transcriptional signatures induced by FDA-approved and experimental drugs (http://lincsproject.org/LINCS/) identified a significant number of putative inhibitors of REDD1 expression among pharmacological class of PI3K/ Akt/mTOR inhibitors $[150,154,157]$ including classical experimental inhibitors such as LY294002 and Wortmannin (WM), and drugs in clinic/clinical trials such as Rapamycin (Rapa) and AZD8055 (Figure 1). This was completely unexpected as PI3K/Akt/mTOR inhibitors block major proproliferative signaling in cells.

The experimental validation of multiple repurposing candidates from this pharmacological class, demonstrated that they indeed inhibited basal and Gcs-induced REDD1 expression in keratinocytes and blood cancer cells in vitro and in mouse skin in vivo (Table 1, [116, 124, 133]). Most of tested PI3K/Akt/mTOR inhibitors also blocked Gcs-induced FKBP51 expression [133]. In addition, we recently showed that Rapamycin inhibited both basal and Dex-induced REDD1 expression in osteocytes (Supplementary Figure 1). This is an important 
finding even though the role of REDD1 in Ges-induced osteoporosis remains to be investigated.

Using two different models of steroid atrophy - skin atrophy and osteoporosis, we validated protective effects of PI3K inhibitors when they and Gcs were delivered either topically or systemically. Indeed, topical application of Rapamycin or LY294002 together with glucocorticoid fluocinolone acetonide (FA) protected mice against FAinduced proliferative block and its atrophic effects in epidermis, dermis and dermal adipose [124, 133]. We also found that systemic co-administration of LY294002 or Rapamycin with Dex protected skin against Dex-induced atrophy. These PI3K inhibitors also normalized RANKL/ OPG ratio and collagen expression in bone indicating a reduction of Dex-induced osteoporosis [116].

Further, we demonstrated that combination of Gcs with PI3K inhibitors did not affect anti-inflammatory activity of Gcs in croton oil ear edema test [124, 133]. Moreover, Rapamycin and LY294002 enhanced antilymphoma effects of Dex in human lymphoma xenograft model, and the therapeutic effects of PI3K inhibitor + Dex combinations ranged from cooperative to synergistic compared to single treatment [150].

One of the most intriguing findings in this work was the ability of several PI3K/Akt/mTOR inhibitors (including Rapamycin, LY294002, Wortmannin, AZD8055) to modify GR function, shifting GR activity towards therapeutically important TR in keratinocytes and lymphoid cells. This was assessed by activation of GRE. Luciferase (for TA) and inhibition of NF-kB Luciferase (for TR), and by global changes in Ges transcriptome validated by Q-PCR of GR target genes (Table 2, [150, $154,157])$. Interestingly, some PI3K/Akt/mTOR inhibitors negatively affected GR phosphorylation at critical for

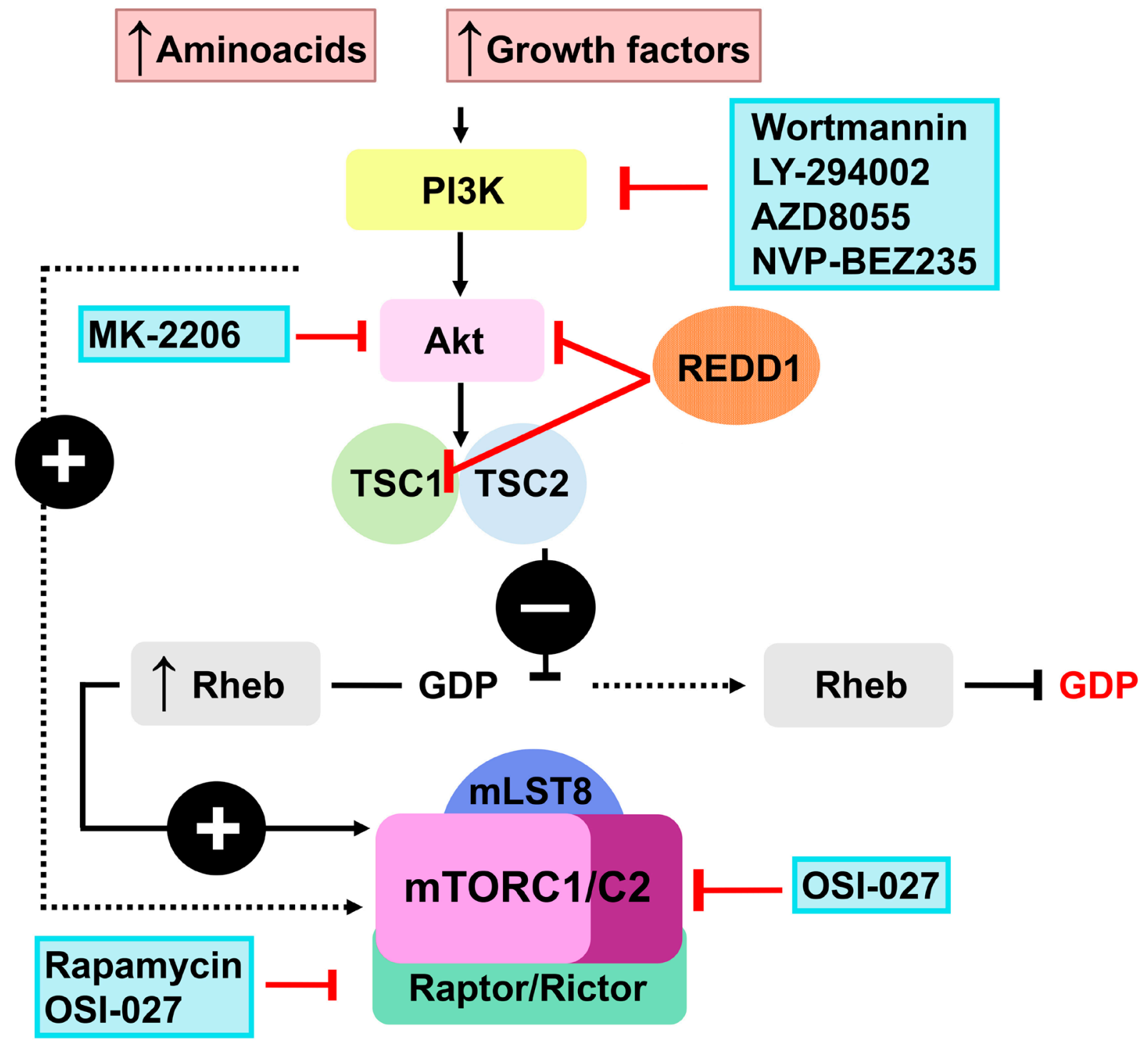

Figure 1: Putative REDD1 inhibitors from the PI3K/Akt/mTOR modulators class. 
Table 2: Effect of PI3K/Akt/mTOR inhibitors on GR function

\begin{tabular}{llll}
\hline Compound & Major Targets & Gene activation by glucocorticoids & Gene inhibition by glucocorticoids \\
\hline Rapamycin & mTORC1 & Blunted (validated array) & Exaggerated (validated array) \\
OSI-027 & mTORC1/2 & N/A & N/A \\
Wortmannin & PI3K & Blunted & Exaggerated \\
LY-294002 & PI3K & Blunted (validated array) & Exaggerated (validated array) \\
NVP-BEZ235 & PI3K/mTOR & N/A & N/A \\
AZD 8055 & PI3K/mTOR & Blunted & Exaggerated \\
MK-2206 & Akt1/2/3 & N/A & N/A \\
\hline
\end{tabular}

HaCaT keratinocytes were pretreated with REDD1 inhibitors (1-10 uM) for hrs, and treated with FA (1 uM) for 6-24 hrs. The level of gene activation/repression was determined by Luciferase reporter assay. References: [137, 140]. Abbreviation: N/A: not assessed.

TA Ser211; GR nuclear translocation; GR loading on REDD1/FKBP51 gene promoters and the expression of other DEGs upregulated by Gcs $[150,154,157]$. At the same time, PI3K/Akt/mTOR inhibitors increased negative effect of Gcs on central pro-inflammatory/proproliferative factor NF-kB and increased down-regulation of cell cycle (Cyclins and Cdks), and pro-inflammatory genes (interleukins, chemokines, cytokines) by Gcs [ $[150$, 154, 157].

Overall, these results provide a proof of principle for using drug repurposing approach to target specific Gcsinduced atrophogenes in selected tissues including skin, muscle and bone.

\section{CONCLUSIONS}

Gcs were introduced in clinic more than 70 years ago, but still remain among most widely used drugs for the treatment of autoimmune and inflammatory diseases and blood cancer. Unfortunately, Gcs are also notorious for multiple metabolic, atrophic and other adverse effects. The extensive efforts to reduce Gcs adverse effects and improve their therapeutic index were initially focused on the development of dissociating GR ligands capable to down-regulate pro-inflammatory genes but lacking Gcs transactivation potential linked to their adverse effects. Overall, the attempts to generate truly dissociating GR activators/modulators (SEGRAM) had limited success, and recently, the approach for SEGRAM design shifted towards GR partial agonists following the strategy successfully used for the development of selective modulators of estrogen receptor. Another promising strategy to reduce Gcs tissue- specific adverse effects is to use them in combination with tissue protectors, which seems to be especially beneficial for prevention/ alleviation of Gcs atrophic effects in skin, muscle and bone. We discussed here in detail a systematic approach to identify the GR target genes causatively involved in atrophic effects of Gcs (atrophogenes) and the search for candidate small molecule drugs (anti-atrophogenes) that could inhibit their expression. Using steroid-induced skin atrophy as a model, we identified and validated REDD1 and FKBP51 as genes central for atrophy in skin and discovered that many $\mathrm{PI} 3 \mathrm{~K} / \mathrm{Akt} / \mathrm{mTOR}$ inhibitors can strongly down-regulate the expression of these atrophogenes in skin, lymphoma cells, and in osteocytes. We proved that PI3K/Akt/mTOR inhibitors can protect skin against atrophy and extended this observation using osteoporosis model. The combination of Gcs with PI3K inhibitors also appeared to be exceptionally promising as it did not affect anti-inflammatory and enhanced antilymphoma activity of Gcs in human xenograft models. Overall, these new approaches suggest feasibility of a really improved safer GR-targeted therapies so much needed for millions of patients with inflammatory, autoimmune diseases and blood cancer.

\section{Abbreviations}

CpdA: Compound A; DEG: differentially expressed genes; Dex: dexamethasone; DDIT4: DNA damage induced transcript 4; FA: fluocinolone acetonide; FKBP5: FK506-binding protein 51; 11ßHSD1: 11 -hydroxysteroid dehydrogenase type 1; Gc(s): glucocorticoid(s); GILZ: glucocorticoid-induced leucine zipper; GR: glucocorticoid receptor; GRE: glucocorticoid responsive elements; LINCS: library of integrated network-based cellular signatures; mTOR: mammalian target of rapamycin; RA: rheumatoid arthritis; REDD1: regulated in development and DNA damage response 1; SEGRAM: selective glucocorticoid receptor agonist/modulator; TA: transactivation; TAT: tyrosine aminotransferase; TF: transcription factor; TR: transrepression.

\section{Author contributions}

Conceptualization: IB; EL, MY. Funding Acquisition: IB; EL, MY. Writing and Editing IB, EL, DC, EZ, KK. Experimental: GB. 


\section{ACKNOWLEDGMENTS}

We acknowledge funding support by R01GM112945, R01AI125366 (to IB), HESI-THRIVE grant (to IB), Russian Science Foundation grant 17-7520124 (to EL).

\section{CONFLICTS OF INTEREST}

Authors have no conflicts of interest to declare.

\section{REFERENCES}

1. Slominski AT, Manna PR, Tuckey RC. On the role of skin in the regulation of local and systemic steroidogenic activities. Steroids. 2015; 103:72-88. https://doi.org/10.1016/j. steroids.2015.04.006. [PubMed]

2. Slominski RM, Raman C, Elmets C, Jetten AM, Slominski AT, Tuckey RC. The significance of CYP11A1 expression in skin physiology and pathology. Mol Cell Endocrinol. 2021; 530:111238. https://doi.org/10.1016/i.mce.2021.111238. [PubMed]

3. Kadmiel M, Cidlowski JA. Glucocorticoid receptor signaling in health and disease. Trends Pharmacol Sci. 2013; 34:518-30. https://doi.org/10.1016/j.tips.2013.07.003. [PubMed]

4. Ramamoorthy S, Cidlowski JA. Corticosteroids: Mechanisms of Action in Health and Disease. Rheum Dis Clin North Am. 2016; 42:15-31. https://doi.org/10.1016/j. rdc.2015.08.002. [PubMed]

5. Oakley RH, Cidlowski JA. The biology of the glucocorticoid receptor: new signaling mechanisms in health and disease. J Allergy Clin Immunol. 2013; 132:1033-44. https://doi. org/10.1016/j.jaci.2013.09.007. [PubMed]

6. Pufall MA. Glucocorticoids and Cancer. Adv Exp Med Biol. 2015; 872:315-33. https://doi.org/10.1007/978-1-49392895-8_14. [PubMed]

7. Lesovaya E, Yemelyanov A, Swart AC, Swart P, Haegeman G, Budunova I. Discovery of Compound A--a selective activator of the glucocorticoid receptor with antiinflammatory and anti-cancer activity. Oncotarget. 2015; 6:30730-44. https://doi.org/10.18632/oncotarget.5078. [PubMed]

8. Kleiman A, Tuckermann JP. Glucocorticoid receptor action in beneficial and side effects of steroid therapy: lessons from conditional knockout mice. Mol Cell Endocrinol. 2007; 275:98-108. https://doi.org/10.1016/j.mce.2007.05.009. [PubMed]

9. Ramamoorthy S, Cidlowski JA. Ligand-induced repression of the glucocorticoid receptor gene is mediated by an NCoR1 repression complex formed by long-range chromatin interactions with intragenic glucocorticoid response elements. Mol Cell Biol. 2013; 33:1711-22. https://doi.org/10.1128/MCB.01151-12. [PubMed]
10. De Bosscher K, Vanden Berghe W, Haegeman G. The interplay between the glucocorticoid receptor and nuclear factor-kappaB or activator protein-1: molecular mechanisms for gene repression. Endocr Rev. 2003; 24:488-522. https:// doi.org/10.1210/er.2002-0006. [PubMed]

11. De Bosscher K, Haegeman G, Elewaut D. Targeting inflammation using selective glucocorticoid receptor modulators. Curr Opin Pharmacol. 2010; 10:497-504. https://doi.org/10.1016/i.coph.2010.04.007. [PubMed]

12. Schoepe S, Schäcke H, May E, Asadullah K. Glucocorticoid therapy-induced skin atrophy. Exp Dermatol. 2006; 15:406-20. https://doi.org/10.1111/j.0906-6705.2006.00435.x. [PubMed]

13. De Bosscher K, Beck IM, Ratman D, Berghe WV, Libert C. Activation of the Glucocorticoid Receptor in Acute Inflammation: the SEDIGRAM Concept. Trends Pharmacol Sci. 2016; 37:4-16. https://doi.org/10.1016/j. tips.2015.09.002. [PubMed]

14. Granner DK, Wang JC, Yamamoto KR. Regulatory Actions of Glucocorticoid Hormones: From Organisms to Mechanisms. Adv Exp Med Biol. 2015; 872:3-31. https:// doi.org/10.1007/978-1-4939-2895-8 1. [PubMed]

15. Chen DW, Lynch JT, Demonacos C, Krstic-Demonacos M, Schwartz JM. Quantitative analysis and modeling of glucocorticoid-controlled gene expression. Pharmacogenomics. 2010; 11:1545-60. https://doi. org/10.2217/pgs.10.125. [PubMed]

16. Reuter KC, Grunwitz CR, Kaminski BM, Steinhilber D, Radeke HH, Stein J. Selective glucocorticoid receptor agonists for the treatment of inflammatory bowel disease: studies in mice with acute trinitrobenzene sulfonic acid colitis. J Pharmacol Exp Ther. 2012; 341:68-80. https://doi. org/10.1124/jpet.111.183947. [PubMed]

17. Coenraads PJ. Hand eczema. N Engl J Med. 2012; 367:182937. https://doi.org/10.1056/NEJMcp1104084. [PubMed]

18. Zen M, Canova M, Campana C, Bettio S, Nalotto L, Rampudda M, Ramonda R, Iaccarino L, Doria A. The kaleidoscope of glucorticoid effects on immune system. Autoimmun Rev. 2011; 10: 305-10. https://doi. org/10.1016/j.autrev.2010.11.009.

19. Chourbaji S, Gass P. Glucocorticoid receptor transgenic mice as models for depression. Brain Res Rev. 2008; 57:554-60. https://doi.org/10.1016/j. brainresrev.2007.04.008. [PubMed]

20. Kiernan DF, Mieler WF. The use of intraocular corticosteroids. Expert Opin Pharmacother. 2009; 10:251125. https://doi.org/10.1517/14656560903160671. [PubMed]

21. Edelman JL. Differentiating intraocular glucocorticoids. Ophthalmologica. 2010 (Suppl 1); 224:25-30. https://doi. org/10.1159/000315158. [PubMed]

22. Clarisse D, Offner F, De Bosscher K. Latest perspectives on glucocorticoid-induced apoptosis and resistance in lymphoid malignancies. Biochim Biophys Acta Rev Cancer. 2020; 1874:188430. https://doi.org/10.1016/j. bbcan.2020.188430. [PubMed] 
23. Holland JF, Freireich EJ. Emil Frei III, 1924-2013. J Clin Oncol. 2013; 31:3727-30. https://doi.org/10.1200/ JCO.2013.51.8126. [PubMed]

24. Lin KT, Wang LH. New dimension of glucocorticoids in cancer treatment. Steroids. 2016; 111:84-88. https://doi. org/10.1016/j.steroids.2016.02.019. [PubMed]

25. Auchus RJ, Yu MK, Nguyen S, Mundle SD. Use of prednisone with abiraterone acetate in metastatic castrationresistant prostate cancer. Oncologist. 2014; 19:1231-40. https://doi.org/10.1634/theoncologist.2014-0167. [PubMed]

26. West DC, Pan D, Tonsing-Carter EY, Hernandez KM, Pierce CF, Styke SC, Bowie KR, Garcia TI, Kocherginsky M, Conzen SD. GR and ER Coactivation Alters the Expression of Differentiation Genes and Associates with Improved ER+ Breast Cancer Outcome. Mol Cancer Res. 2016; 14:707-19. https://doi.org/10.1158/1541-7786.MCR15-0433. [PubMed]

27. Tonsing-Carter E, Hernandez KM, Kim CR, Harkless RV, Oh A, Bowie KR, West-Szymanski DC, Betancourt-Ponce MA, Green BD, Lastra RR, Fleming GF, Chandarlapaty S, Conzen SD. Glucocorticoid receptor modulation decreases ER-positive breast cancer cell proliferation and suppresses wild-type and mutant ER chromatin association. Breast Cancer Res. 2019; 21:82. https://doi.org/10.1186/s13058019-1164-6. [PubMed]

28. Zhidkova EM, Lylova ES, Savinkova AV, Mertsalov SA, Kirsanov KI, Belitsky GA, Yakubovskaya MG, Lesovaya EA. A Brief Overview of the Paradoxical Role of Glucocorticoids in Breast Cancer. Breast Cancer (Auckl). 2020; 14:1178223420974667. https://doi. org/10.1177/1178223420974667. [PubMed]

29. Lili LN, Klopot A, Readhead B, Baida G, Dudley JT, Budunova I. Transcriptomic Network Interactions in Human Skin Treated with Topical Glucocorticoid Clobetasol Propionate. J Invest Dermatol. 2019; 139:2281-91. https:// doi.org/10.1016/i.jid.2019.04.021. [PubMed]

30. https://www.transparencymarketresearch.com/ glucocorticoid-drugs-market.html.

31. Pimenta E, Wolley M, Stowasser M. Adverse cardiovascular outcomes of corticosteroid excess. Endocrinology. 2012; 153:5137-42. https://doi.org/10.1210/en.2012-1573. [PubMed]

32. Farman N, Rafestin-Oblin ME. Multiple aspects of mineralocorticoid selectivity. Am J Physiol Renal Physiol. 2001; 280:F181-92. https://doi.org/10.1152/ ajprenal.2001.280.2.F181. [PubMed]

33. Silverman MN, Sternberg EM. Glucocorticoid regulation of inflammation and its functional correlates: from HPA axis to glucocorticoid receptor dysfunction. Ann N Y Acad Sci. 2012; 1261:55-63. https://doi.org/10.1111/j.17496632.2012.06633.x. [P PubMed]

34. de Guia RM, Rose AJ, Herzig S. Glucocorticoid hormones and energy homeostasis. Horm Mol Biol Clin Investig. 2014; 19:117-28. https://doi.org/10.1515/hmbci-2014-0021. [PubMed]
35. Rafacho A, Ortsäter H, Nadal A, Quesada I. Glucocorticoid treatment and endocrine pancreas function: implications for glucose homeostasis, insulin resistance and diabetes. J Endocrinol. 2014; 223:R49-62. https://doi.org/10.1530/ JOE-14-0373. [PubMed]

36. Canalis E, Delany AM. Mechanisms of glucocorticoid action in bone. Ann N Y Acad Sci. 2002; 966:73-81. https:// doi.org/10.1111/j.1749-6632.2002.tb04204.x. [PubMed]

37. Baida G, Bhalla P, Kirsanov K, Lesovaya E, Yakubovskaya M, Yuen K, Guo S, Lavker RM, Readhead B, Dudley JT, Budunova I. REDD1 functions at the crossroads between the therapeutic and adverse effects of topical glucocorticoids. EMBO Mol Med. 2015; 7:42-58. https:// doi.org/10.15252/emmm.201404601. [PubMed]

38. Hanaoka BY, Peterson CA, Crofford LJ. Glucocorticoid effects on skeletal muscle: benefit and risk in patients with autoimmune inflammatory rheumatoid diseases. Expert Rev Clin Immunol. 2012; 8:695-97. https://doi.org/10.1586/ eci.12.76. [PubMed]

39. Laakso M, Edelman SV, Olefsky JM, Brechtel G, Wallace $\mathrm{P}$, Baron AD. Kinetics of in vivo muscle insulin-mediated glucose uptake in human obesity. Diabetes. 1990; 39:96574. https://doi.org/10.2337/diab.39.8.965. [PubMed]

40. Peckett AJ, Wright DC, Riddell MC. The effects of glucocorticoids on adipose tissue lipid metabolism. Metabolism. 2011; 60:1500-10. https://doi.org/10.1016/j. metabol.2011.06.012. [PubMed]

41. Abulizi A, Camporez JP, Jurczak MJ, Høyer KF, Zhang D, Cline GW, Samuel VT, Shulman GI, Vatner DF. Adipose glucocorticoid action influences whole-body metabolism via modulation of hepatic insulin action. FASEB J. 2019; 33:817485. https://doi.org/10.1096/fj.201802706R. [ubMed]

42. Rivera-Gonzalez GC, Klopot A, Sabin K, Baida G, Horsley V, Budunova I. Regulated in Development and DNA Damage Responses 1 Prevents Dermal Adipocyte Differentiation and Is Required for Hair Cycle-Dependent Dermal Adipose Expansion. J Invest Dermatol. 2020; 140:1698-705.e1. https://doi.org/10.1016/j.jid.2019.12.033. [PubMed]

43. García-Eguren G, Sala-Vila A, Giró O, Vega-Beyhart A, Hanzu FA. Long-term hypercortisolism induces lipogenesis promoting palmitic acid accumulation and inflammation in visceral adipose tissue compared with HFD-induced obesity. Am J Physiol Endocrinol Metab. 2020; 318:E995-1003. https://doi.org/10.1152/ajpendo.00516.2019. [PubMed]

44. Chimin P, Farias Tda S, Torres-Leal FL, Bolsoni-Lopes A, Campaña AB, Andreotti S, Lima FB. Chronic glucocorticoid treatment enhances lipogenic activity in visceral adipocytes of male Wistar rats. Acta Physiol (Oxf). 2014; 211:409-20. https://doi.org/10.1111/apha.12226. [PubMed]

45. Gathercole LL, Morgan SA, Bujalska IJ, Hauton D, Stewart PM, Tomlinson JW. Regulation of lipogenesis by glucocorticoids and insulin in human adipose tissue. PLoS One. 2011; 6:e26223. https://doi.org/10.1371/journal. pone.0026223. [PubMed] 
46. Compston J. Glucocorticoid-induced osteoporosis: an update. Endocrine. 2018; 61:7-16. https://doi.org/10.1007/ s12020-018-1588-2. [PubMed]

47. Schäcke H, Döcke WD, Asadullah K. Mechanisms involved in the side effects of glucocorticoids. Pharmacol Ther. 2002; 96:23-43. https://doi.org/10.1016/s0163-7258(02)00297-8. [PubMed]

48. Wu J, Zeng Z, Li Y, Qin H, Zuo C, Zhou C, Xu D. Cycloastragenol protects against glucocorticoid-induced osteogenic differentiation inhibition by activating telomerase. Phytother Res. 2021; 35:2034-44. https://doi. org/10.1002/ptr.6946. [PubMed]

49. Shan C, Yue J, Liu W. Broadening the role of osteocalcin in the hypothalamic-pituitary-gonadal axis. J Endocrinol. 2021; 249:R43-51. https://doi.org/10.1530/JOE-20-0203. [PubMed]

50. Hanaoka BY, Peterson CA, Horbinski C, Crofford LJ. Implications of glucocorticoid therapy in idiopathic inflammatory myopathies. Nat Rev Rheumatol. 2012; 8:448-57. https://doi.org/10.1038/nrrheum.2012.85. [PubMed]

51. Britto FA, Cortade F, Belloum Y, Blaquière M, Gallot YS, Docquier A, Pagano AF, Jublanc E, Bendridi N, KoechlinRamonatxo C, Chabi B, Francaux M, Casas F, et al. Glucocorticoid-dependent REDD1 expression reduces muscle metabolism to enable adaptation under energetic stress. BMC Biol. 2018; 16:65. https://doi.org/10.1186/ s12915-018-0525-4. [PubMed]

52. Schoepe S, Schäcke H, Bernd A, Zöller N, Asadullah $\mathrm{K}$. Identification of novel in vitro test systems for the determination of glucocorticoid receptor ligand-induced skin atrophy. Skin Pharmacol Physiol. 2010; 23:139-51. https://doi.org/10.1159/000270386. [PubMed]

53. Chebotaev D, Yemelyanov A, Budunova I. The mechanisms of tumor suppressor effect of glucocorticoid receptor in skin. Mol Carcinog. 2007; 46:732-40. https://doi. org $/ 10.1002 / \mathrm{mc} .20349$. [PubMed]

54. Schäcke H, Rehwinkel H, Asadullah K, Cato AC. Insight into the molecular mechanisms of glucocorticoid receptor action promotes identification of novel ligands with an improved therapeutic index. Exp Dermatol. 2006; 15:56573. https://doi.org/10.1111/j.1600-0625.2006.00453.x. [PubMed]

55. Stojadinovic O, Lee B, Vouthounis C, Vukelic S, Pastar I, Blumenberg M, Brem H, Tomic-Canic M. Novel genomic effects of glucocorticoids in epidermal keratinocytes: inhibition of apoptosis, interferon-gamma pathway, and wound healing along with promotion of terminal differentiation. J Biol Chem. 2007; 282:4021-34. https:// doi.org/10.1074/jbc.M606262200. [PubMed]

56. Terao M, Katayama I. Local cortisol/corticosterone activation in skin physiology and pathology. J Dermatol Sci. 2016; 84:11-16. https://doi.org/10.1016/j. jdermsci.2016.06.014. [PubMed]
57. Baida G, Bhalla P, Yemelyanov A, Stechschulte LA, Shou W, Readhead B, Dudley JT, Sánchez ER, Budunova I. Deletion of the glucocorticoid receptor chaperone FKBP51 prevents glucocorticoid-induced skin atrophy. Oncotarget. 2018; 9:34772-83. https://doi.org/10.18632/ oncotarget.26194. [PubMed]

58. Miner JN, Hong MH, Negro-Vilar A. New and improved glucocorticoid receptor ligands. Expert Opin Investig Drugs. 2005; 14:1527-45. https://doi.org/10.1517/135437 84.14.12.1527. [PubMed]

59. Rosen J, Miner JN. The search for safer glucocorticoid receptor ligands. Endocr Rev. 2005; 26:452-64. https://doi. org/10.1210/er.2005-0002. [PubMed]

60. Buttgereit F, Gibofsky A. Delayed-release prednisone - a new approach to an old therapy. Expert Opin Pharmacother. 2013; 14:1097-106. https://doi.org/10.1517/14656566.2013 .782001. [PubMed]

61. Vandevyver S, Dejager L, Tuckermann J, Libert C. New insights into the anti-inflammatory mechanisms of glucocorticoids: an emerging role for glucocorticoid-receptormediated transactivation. Endocrinology. 2013; 154:9931007. https://doi.org/10.1210/en.2012-2045. [PubMed]

62. Paul-Clark MJ, Mancini L, Del Soldato P, Flower RJ, Perretti M. Potent antiarthritic properties of a glucocorticoid derivative, NCX-1015, in an experimental model of arthritis. Proc Natl Acad Sci U S A. 2002; 99:1677-82. https://doi.org/10.1073/pnas.022641099. [PubMed]

63. Belvisi MG, Hele DJ. Soft steroids: a new approach to the treatment of inflammatory airways diseases. Pulm Pharmacol Ther. 2003; 16:321-25. https://doi.org/10.1016/ S1094-5539(03)00105-6. [PubMed]

64. Vayssière BM, Dupont S, Choquart A, Petit F, Garcia T, Marchandeau C, Gronemeyer H, Resche-Rigon M. Synthetic glucocorticoids that dissociate transactivation and AP-1 transrepression exhibit antiinflammatory activity in vivo. Mol Endocrinol. 1997; 11:1245-55. https://doi. org $/ 10.1210 /$ mend.11.9.9979. [PubMed]

65. Schäcke H, Zollner TM, Döcke WD, Rehwinkel H, Jaroch S, Skuballa W, Neuhaus R, May E, Zügel U, Asadullah K. Characterization of ZK 245186, a novel, selective glucocorticoid receptor agonist for the topical treatment of inflammatory skin diseases. Br J Pharmacol. 2009; 158:1088-103. https://doi.org/10.1111/j.14765381.2009.00238.x. [PubMed]

66. Spinelli SL, Xi X, McMillan DH, Woeller CF, Richardson ME, Cavet ME, Zhang JZ, Feldon SE, Phipps RP. Mapracorat, a selective glucocorticoid receptor agonist, upregulates RelB, an anti-inflammatory nuclear factor-kappaB protein, in human ocular cells. Exp Eye Res. 2014; 127:290-98. https:// doi.org/10.1016/j.exer.2014.07.013. [PubMed]

67. Bäumer W, Rossbach K, Schmidt BH. The selective glucocorticoid receptor agonist mapracorat displays a favourable safety-efficacy ratio for the topical treatment of inflammatory skin diseases in dogs. Vet Dermatol. 2017; 28:46-e11. https://doi.org/10.1111/vde.12315. [PubMed] 
68. Hua G, Zein N, Paulen L, Chambon P. The glucocorticoid receptor agonistic modulators $\mathrm{CpdX}$ and $\mathrm{CpdX}-\mathrm{D} 3$ do not generate the debilitating effects of synthetic glucocorticoids. Proc Natl Acad Sci U S A. 2019; 116:14200-09. https://doi. org/10.1073/pnas.1908264116. [PubMed]

69. Hua G, Zein N, Daubeuf F, Chambon P. Glucocorticoid receptor modulators $\mathrm{CpdX}$ and $\mathrm{CpdX}-\mathrm{D} 3$ exhibit the same in vivo antiinflammatory activities as synthetic glucocorticoids. Proc Natl Acad Sci U S A. 2019; 116:14191-99. https://doi. org/10.1073/pnas.1908258116. [PubMed]

70. Buttgereit F, Strand V, Lee EB, Simon-Campos A, McCabe D, Genet A, Tammara B, Rojo R, Hey-Hadavi J. Fosdagrocorat (PF-04171327) versus prednisone or placebo in rheumatoid arthritis: a randomised, double-blind, multicentre, phase IIb study. RMD Open. 2019; 5:e000889. https://doi.org/10.1136/rmdopen-2018-000889. [PubMed]

71. Weatherley B, McFadyen L, Tammara B. Population Pharmacokinetics of Fosdagrocorat (PF-04171327), a Dissociated Glucocorticoid Receptor Agonist, in Patients With Rheumatoid Arthritis. Clin Transl Sci. 2018; 11:54 62. https://doi.org/10.1111/cts.12515. [PubMed]

72. Kuna P, Aurivillius M, Jorup C, Prothon S, Taib Z, Edsbäcker S. Efficacy and Tolerability of an Inhaled Selective Glucocorticoid Receptor Modulator - AZD5423 in Chronic Obstructive Pulmonary Disease Patients: Phase II Study Results. Basic Clin Pharmacol Toxicol. 2017; 121:279-89. https://doi.org/10.1111/bcpt.12768. [PubMed]

73. Edman K, Ahlgren R, Bengtsson M, Bladh H, Bäckström S, Dahmén J, Henriksson K, Hillertz P, Hulikal V, Jerre A, Kinchin L, Kåse C, Lepistö M, et al. The discovery of potent and selective non-steroidal glucocorticoid receptor modulators, suitable for inhalation. Bioorg Med Chem Lett. 2014; 24:2571-77. https://doi.org/10.1016/j. bmcl.2014.03.070. [PubMed]

74. Gauvreau GM, Boulet LP, Leigh R, Cockcroft DW, Killian KJ, Davis BE, Deschesnes F, Watson RM, Swystun V, Mårdh CK, Wessman P, Jorup C, Aurivillius M, O'Byrne PM. A nonsteroidal glucocorticoid receptor agonist inhibits allergen-induced late asthmatic responses. Am J Respir Crit Care Med. 2015; 191:161-67. https://doi.org/10.1164/ rccm.201404-06230C. [PubMed]

75. Brown MN, Fuhr R, Beier J, Su HL, Chen Y, Forsman H, Hamrén UW, Jackson H, Aggarwal A. Efficacy and safety of AZD7594, an inhaled non-steroidal selective glucocorticoid receptor modulator, in patients with asthma: a phase $2 \mathrm{a}$ randomized, double blind, placebo-controlled crossover trial. Respir Res. 2019; 20:37. https://doi.org/10.1186/ s12931-019-1000-7. [PubMed]

76. Hemmerling M, Nilsson S, Edman K, Eirefelt S, Russell W, Hendrickx R, Johnsson E, Kärrman Mårdh C, Berger M, Rehwinkel H, Abrahamsson A, Dahmén J, Eriksson AR, et al. Selective Nonsteroidal Glucocorticoid Receptor Modulators for the Inhaled Treatment of Pulmonary Diseases. J Med Chem. 2017; 60:8591-605. https://doi. org/10.1021/acs.jmedchem.7b01215. [ubMed]
77. Ripa L, Edman K, Dearman M, Edenro G, Hendrickx R, Ullah V, Chang HF, Lepistö M, Chapman D, Geschwindner S, Wissler L, Svanberg P, Lawitz K, et al. Discovery of a Novel Oral Glucocorticoid Receptor Modulator (AZD9567) with Improved Side Effect Profile. J Med Chem. 2018; 61:1785-99. https://doi.org/10.1021/acs. imedchem.7b01690. [PubMed]

78. Stahn C, Löwenberg M, Hommes DW, Buttgereit F. Molecular mechanisms of glucocorticoid action and selective glucocorticoid receptor agonists. Mol Cell Endocrinol. 2007; 275:71-78. https://doi.org/10.1016/j. mce.2007.05.019. [PubMed]

79. Schäcke H, Schottelius A, Döcke WD, Strehlke P, Jaroch S, Schmees N, Rehwinkel H, Hennekes H, Asadullah K. Dissociation of transactivation from transrepression by a selective glucocorticoid receptor agonist leads to separation of therapeutic effects from side effects. Proc Natl Acad Sci U S A. 2004; 101:227-32. https://doi.org/10.1073/ pnas.0300372101. [PubMed]

80. Chirumamilla CS, Palagani A, Kamaraj B, Declerck K, Verbeek MWC, Oksana R, De Bosscher K, Bougarne N, Ruttens B, Gevaert K, Houtman R, De Vos WH, Joossens $\mathrm{J}$, et al. Selective Glucocorticoid Receptor Properties of GSK866 Analogs with Cysteine Reactive Warheads. Front Immunol. 2017; 8:1324. https://doi.org/10.3389/ fimmu.2017.01324. [PubMed]

81. Dack KN, Johnson PS, Henriksson K, Eirefelt S, Carnerup MA, Stahlhut M, Ollerstam AK. Topical 'dual-soft' glucocorticoid receptor agonist for dermatology. Bioorg Med Chem Lett. 2020; 30:127402. https://doi.org/10.1016/j. bmcl.2020.127402. [PubMed]

82. Oldfield E, Lin FY. Terpene biosynthesis: modularity rules. Angew Chem Int Ed Engl. 2012; 51:1124-37. https://doi. org/10.1002/anie.201103110. [ [PubMed]

83. Goldstein JL, Brown MS. Regulation of the mevalonate pathway. Nature. 1990; 343:425-30. https://doi. org/10.1038/343425a0. [ [ PubMed]

84. Dean M, Murphy BT, Burdette JE. Phytosteroids beyond estrogens: Regulators of reproductive and endocrine function in natural products. Mol Cell Endocrinol. 2017; 442:98-105. https://doi.org/10.1016/j.mce.2016.12.013. [PubMed]

85. Haridas V, Xu ZX, Kitchen D, Jiang A, Michels P, Gutterman JU. The anticancer plant triterpenoid, avicin D, regulates glucocorticoid receptor signaling: implications for cellular metabolism. PLoS One. 2011; 6:e28037. https://doi. org/10.1371/journal.pone.0028037. [PubMed]

86. Souffriau J, Eggermont M, Van Ryckeghem S, Van Looveren K, Van Wyngene L, Van Hamme E, Vuylsteke M, Beyaert R, De Bosscher K, Libert C. A screening assay for Selective Dimerizing Glucocorticoid Receptor Agonists and Modulators (SEDIGRAM) that are effective against acute inflammation. Sci Rep. 2018; 8:12894. https://doi. org/10.1038/s41598-018-31150-w. [PubMed]

87. Austin JR, Kirkpatrick BJ, Rodríguez RR, Johnson ME, Lantvit DD, Burdette JE. Baicalein Is a Phytohormone 
that Signals Through the Progesterone and Glucocorticoid Receptors. Horm Cancer. 2020; 11:97-110. https://doi. org/10.1007/s12672-020-00382-6. [PubMed]

88. Leung KW, Leung FP, Huang Y, Mak NK, Wong RN. Nongenomic effects of ginsenoside-Re in endothelial cells via glucocorticoid receptor. FEBS Lett. 2007; 581:2423-28. https://doi.org/10.1016/j.febslet.2007.04.055. [PubMed]

89. Yang CS, Ko SR, Cho BG, Shin DM, Yuk JM, Li S, Kim JM, Evans RM, Jung JS, Song DK, Jo EK. The ginsenoside metabolite compound $\mathrm{K}$, a novel agonist of glucocorticoid receptor, induces tolerance to endotoxin-induced lethal shock. J Cell Mol Med. 2008; 12:1739-53. https://doi. org/10.1111/j.1582-4934.2007.00181.x. [PubMed]

90. Li Y. [Relationship between glucocorticoid receptor and deficiency syndrome and the regulation of traditional Chinese medicine]. [Article in Chinese]. Zhong Xi Yi Jie He Xue Bao. 2004; 2:172-74. [PubMed]

91. Choi D, Kang W, Park S, Son B, Park T. $\beta$-Ionone Attenuates Dexamethasone-Induced Suppression of Collagen and Hyaluronic Acid Synthesis in Human Dermal Fibroblasts. Biomolecules. 2021; 11:619. https://doi. org/10.3390/biom11050619. [PubMed]

92. Zhao SQ, Xu SQ, Cheng J, Cao XL, Zhang Y, Zhou WP, Huang YJ, Wang J, Hu XM. Anti-inflammatory effect of external use of escin on cutaneous inflammation: possible involvement of glucocorticoids receptor. Chin J Nat Med. 2018; 16:105-12. https://doi.org/10.1016/S18755364(18)30036-0. [PubMed]

93. Xin W, Zhang L, Fan H, Jiang N, Wang T, Fu F. Escin attenuates acute lung injury induced by endotoxin in mice. Eur J Pharm Sci. 2011; 42:73-80. https://doi.org/10.1016/j. ejps.2010.10.008. [PubMed]

94. Brinker AM, Ma J, Lipsky PE, Raskin I. Medicinal chemistry and pharmacology of genus Tripterygium (Celastraceae). Phytochemistry. 2007; 68:732-66. https:// doi.org/10.1016/j.phytochem.2006.11.029. [PubMed]

95. Kang C, Kim S, Lee E, Ryu J, Lee M, Kwon Y. Genetically Encoded Sensor Cells for the Screening of Glucocorticoid Receptor (GR) Effectors in Herbal Extracts. Biosensors (Basel). 2021; 11:341. https://doi.org/10.3390/ bios11090341. [PubMed]

96. Ryu J, Lee E, Kang C, Lee M, Kim S, Park S, Lee DY, Kwon Y. Rapid Screening of Glucocorticoid Receptor (GR) Effectors Using Cortisol-Detecting Sensor Cells. Int J Mol Sci. 2021; 22:4747. https://doi.org/10.3390/ijms22094747. [PubMed]

97. Liu HS, Shi HL, Huang F, Peterson KE, Wu H, Lan YY, Zhang BB, He YX, Woods T, Du M, Wu XJ, Wang ZT. Astragaloside IV inhibits microglia activation via glucocorticoid receptor mediated signaling pathway. Sci Rep. 2016; 6:19137. https://doi.org/10.1038/srep19137. [PubMed]

98. Karra AG, Tziortziou M, Kylindri P, Georgatza D, Gorgogietas VA, Makiou A, Krokida A, Tsialtas I, Kalousi FD, Papadopoulos GE, Papadopoulou KK, Psarra AG.
Boswellic acids and their derivatives as potent regulators of glucocorticoid receptor actions. Arch Biochem Biophys. 2020; 695:108656. https://doi.org/10.1016/j. abb.2020.108656. [PubMed]

99. Liang Y, Zhang T, Zhao J, Li C, Zou H, Li F, Zhang J, Ren L. Glucocorticoid receptor-mediated alleviation of inflammation by berberine: in vitro, in silico and in vivo investigations. Food Funct. 2021; 12:11974-86. https://doi. org/10.1039/d1fo01612a. [PubMed]

100. Aoyagi S, Archer TK. Differential glucocorticoid receptormediated transcription mechanisms. J Biol Chem. 2011; 286:4610-19. https://doi.org/10.1074/jbc.M110.195040. [PubMed]

101. Yoshioka Y, Samukawa Y, Yamashita Y, Ashida H. 4-Hydroxyderricin and xanthoangelol isolated from Angelica keiskei prevent dexamethasone-induced muscle loss. Food Funct. 2020; 11:5498-512. https://doi. org/10.1039/d0fo00720j. [PubMed]

102. Juan YC, Chang CC, Tsai WJ, Lin YL, Hsu YS, Liu HK. Pharmacological evaluation of insulin mimetic novel suppressors of PEPCK gene transcription from Paeoniae Rubra Radix. J Ethnopharmacol. 2011; 137:592-600. https://doi.org/10.1016/j.jep.2011.06.007. [PubMed]

103. Kuntzsch D, Bergann T, Dames P, Fromm A, Fromm M, Davis RA, Melzig MF, Schulzke JD. The plant-derived glucocorticoid receptor agonist Endiandrin A acts as costimulator of colonic epithelial sodium channels $(\mathrm{ENaC})$ via SGK-1 and MAPKs. PLoS One. 2012; 7:e49426. https:// doi.org/10.1371/journal.pone.0049426. [PubMed]

104. He M, Halima M, Xie Y, Schaaf MJM, Meijer AH, Wang M. Ginsenoside Rg1 Acts as a Selective Glucocorticoid Receptor Agonist with Anti-Inflammatory Action without Affecting Tissue Regeneration in Zebrafish Larvae. Cells. 2020; 9:1107. https://doi.org/10.3390/cells9051107. [PubMed]

105. Seo JH, Jin MH, Chang YH. Anti-inflammatory effect of Salsola komarovii extract with dissociated glucocorticoid activity. BMC Complement Med Ther. 2020; 20:176. https://doi.org/10.1186/s12906-020-02979-4. [PubMed]

106. Sergeant CA, Africander D, Swart P, Swart AC. Sutherlandia frutescens modulates adrenal hormone biosynthesis, acts as a selective glucocorticoid receptor agonist (SEGRA) and displays anti-mineralocorticoid properties. J Ethnopharmacol. 2017; 202:290-301. https:// doi.org/10.1016/j.jep.2017.03.019. [PubMed]

107. Wu X, Wu J, Xia S, Li B, Dong J. Icaritin opposes the development of social aversion after defeat stress via increases of GR mRNA and BDNF mRNA in mice. Behav Brain Res. 2013; 256:602-08. https://doi.org/10.1016/j. bbr.2013.09.034. [PubMed]

108. Song W, Liu M, Wu J, Zhai H, Chen Y, Peng Z. Preclinical Pharmacokinetics of Triptolide: A Potential Antitumor Drug. Curr Drug Metab. 2019; 20:147-54. https://doi.org/1 $\underline{0.2174 / 1389200219666180816141506}$. [PubMed] 
109. El-Baba C, Baassiri A, Kiriako G, Dia B, Fadlallah S, Moodad S, Darwiche N. Terpenoids' anti-cancer effects: focus on autophagy. Apoptosis. 2021; 26:491-511. https:// doi.org/10.1007/s10495-021-01684-y. [PubMed]

110. Zhang T, Liang Y, Zhang J. Natural and synthetic compounds as dissociated agonists of glucocorticoid receptor. Pharmacol Res. 2020; 156:104802. https://doi. org/10.1016/j.phrs.2020.104802. [PubMed]

111. Ichim MC, de Boer HJ. A Review of Authenticity and Authentication of Commercial Ginseng Herbal Medicines and Food Supplements. Front Pharmacol. 2021; 11:612071. https://doi.org/10.3389/fphar.2020.612071. [PubMed]

112. Xi C, Peng S, Wu Z, Zhou Q, Zhou J. Toxicity of triptolide and the molecular mechanisms involved. Biomed Pharmacother. 2017; 90:531-41. https://doi.org/10.1016/j. biopha.2017.04.003. [PubMed]

113. Zhang J, Wu C, Gao L, Du G, Qin X. Astragaloside IV derived from Astragalus membranaceus: A research review on the pharmacological effects. Adv Pharmacol. 2020; 87:89112. https://doi.org/10.1016/bs.apha.2019.08.002. [PubMed]

114. Yemelyanov A, Czwornog J, Gera L, Joshi S, Chatterton RT Jr, Budunova I. Novel steroid receptor phyto-modulator compound a inhibits growth and survival of prostate cancer cells. Cancer Res. 2008; 68:4763-73. https://doi. org/10.1158/0008-5472.CAN-07-6104. [PubMed]

115. De Bosscher K. Selective Glucocorticoid Receptor modulators. J Steroid Biochem Mol Biol. 2010; 120:96-104. https://doi.org/10.1016/j.jsbmb.2010.02.027. [PubMed]

116. De Bosscher K, Vanden Berghe W, Beck IM, Van Molle W, Hennuyer N, Hapgood J, Libert C, Staels B, Louw A, Haegeman G. A fully dissociated compound of plant origin for inflammatory gene repression. Proc Natl Acad Sci U S A. 2005; 102:15827-32. https://doi.org/10.1073/ pnas.0505554102. [PubMed]

117. Lesovaya E, Yemelyanov A, Kirsanov K, Popa A, Belitsky G, Yakubovskaya M, Gordon LI, Rosen ST, Budunova I. Combination of a selective activator of the glucocorticoid receptor Compound A with a proteasome inhibitor as a novel strategy for chemotherapy of hematologic malignancies. Cell Cycle. 2013; 12:133-44. https://doi. org/10.4161/cc.23048. [PubMed]

118. Klopot A, Baida G, Bhalla P, Haegeman G, Budunova I. Selective Activator of the Glucocorticoid Receptor Compound A Dissociates Therapeutic and Atrophogenic Effects of Glucocorticoid Receptor Signaling in Skin. J Cancer Prev. 2015; 20:250-59. https://doi.org/10.15430/ JCP.2015.20.4.250. [PubMed]

119. Gossye V, Elewaut D, Van Beneden K, Dewint P, Haegeman G, De Bosscher K. A plant-derived glucocorticoid receptor modulator attenuates inflammation without provoking ligand-induced resistance. Ann Rheum Dis. 2010; 69:29196. https://doi.org/10.1136/ard.2008.102871. [PubMed]

120. Dewint P, Gossye V, De Bosscher K, Vanden Berghe W, Van Beneden K, Deforce D, Van Calenbergh S, Müller-
Ladner U, Vander Cruyssen B, Verbruggen G, Haegeman G, Elewaut D. A plant-derived ligand favoring monomeric glucocorticoid receptor conformation with impaired transactivation potential attenuates collagen-induced arthritis. J Immunol. 2008; 180:2608-15. https://doi. org/10.4049/jimmunol.180.4.2608. [PubMed]

121. van Loo G, Sze M, Bougarne N, Praet J, Mc Guire C, Ullrich A, Haegeman G, Prinz M, Beyaert R, De Bosscher K. Antiinflammatory properties of a plantderived nonsteroidal, dissociated glucocorticoid receptor modulator in experimental autoimmune encephalomyelitis. Mol Endocrinol. 2010; 24:310-22. https://doi.org/10.1210/ me.2009-0236. [PubMed]

122. Schäcke H, Berger $M$, Rehwinkel H, Asadullah K. Selective glucocorticoid receptor agonists (SEGRAs): novel ligands with an improved therapeutic index. Mol Cell Endocrinol. 2007; 275:109-17. https://doi.org/10.1016/j. mce.2007.05.014. [PubMed]

123. Van Moortel L, Gevaert K, De Bosscher K. Improved Glucocorticoid Receptor Ligands: Fantastic Beasts, but How to Find Them? Front Endocrinol (Lausanne). 2020; 11:559673. https://doi.org/10.3389/fendo.2020.559673. [PubMed]

124. Gu L, Zhou C, Liu H, Gao J, Li Q, Mu D, Ma Z. Rapamycin sensitizes T-ALL cells to dexamethasone-induced apoptosis. J Exp Clin Cancer Res. 2010; 29:150. https:// doi.org/10.1186/1756-9966-29-150. [PubMed]

125. Ronchetti S, Ayroldi E, Ricci E, Gentili M, Migliorati G, Riccardi C. A Glance at the Use of Glucocorticoids in Rare Inflammatory and Autoimmune Diseases: Still an Indispensable Pharmacological Tool? Front Immunol. 2021; 11:613435. https://doi.org/10.3389/fimmu.2020.613435. [PubMed]

126. Ratman D, Vanden Berghe W, Dejager L, Libert C, Tavernier J, Beck IM, De Bosscher K. How glucocorticoid receptors modulate the activity of other transcription factors: a scope beyond tethering. Mol Cell Endocrinol. 2013; 380:41-54. https://doi.org/10.1016/j.mce.2012.12.014. [PubMed]

127. Desmet SJ, De Bosscher K. Glucocorticoid receptors: finding the middle ground. J Clin Invest. 2017; 127:113645. https://doi.org/10.1172/JCI88886. [PubMed]

128. Mitchner NA, Harris ST. Current and emerging therapies for osteoporosis. J Fam Pract. 2009; 58:S45-49. [ubMed]

129. Shen G, Ren H, Shang Q, Qiu T, Yu X, Zhang Z, Huang J, Zhao W, Zhang Y, Liang, Jiang X. Autophagy as a target for glucocorticoid-induced osteoporosis therapy. Cell Mol Life Sci. 2018; 75:2683-93. https://doi.org/10.1007/s00018-0182776-1. [PubMed]

130. Johannesdottir SA, Horváth-Puhó E, Dekkers OM, Cannegieter SC, Jørgensen JO, Ehrenstein V, Vandenbroucke JP, Pedersen L, Sørensen HT. Use of glucocorticoids and risk of venous thromboembolism: a nationwide population-based case-control study. JAMA Intern Med. 2013; 173:743-52. https://doi.org/10.1001/ jamainternmed.2013.122. [PubMed] 
131. van Zaane B, Nur E, Squizzato A, Gerdes VE, Büller HR, Dekkers OM, Brandjes DP. Systematic review on the effect of glucocorticoid use on procoagulant, anti-coagulant and fibrinolytic factors. J Thromb Haemost. 2010; 8:2483-93. https://doi.org/10.1111/j.1538-7836.2010.04034.x. [PubMed]

132. Zimmermann GR, Avery W, Finelli AL, Farwell M, Fraser CC, Borisy AA. Selective amplification of glucocorticoid anti-inflammatory activity through synergistic multi-target action of a combination drug. Arthritis Res Ther. 2009; 11:R12. https://doi.org/10.1186/ar2602. [PubMed]

133. Oakley RH, Revollo J, Cidlowski JA. Glucocorticoids regulate arrestin gene expression and redirect the signaling profile of $\mathrm{G}$ protein-coupled receptors. Proc Natl Acad Sci U S A. 2012; 109:17591-96. https://doi.org/10.1073/ pnas.1209411109. [PubMed]

134. Strömberg T, Dimberg A, Hammarberg A, Carlson K, Osterborg A, Nilsson K, Jernberg-Wiklund H. Rapamycin sensitizes multiple myeloma cells to apoptosis induced by dexamethasone. Blood. 2004; 103:3138-47. https://doi. org/10.1182/blood-2003-05-1543. [PubMed]

135. Wei G, Twomey D, Lamb J, Schlis K, Agarwal J, Stam RW, Opferman JT, Sallan SE, den Boer ML, Pieters R, Golub TR, Armstrong SA. Gene expression-based chemical genomics identifies rapamycin as a modulator of MCL1 and glucocorticoid resistance. Cancer Cell. 2006; 10:331-42. https://doi.org/10.1016/j.ccr.2006.09.006. [PubMed]

136. Clarisse D, Van Wesemael K, Tavernier J, Offner F, Beck IM, De Bosscher K. Effect of combining glucocorticoids with Compound A on glucocorticoid receptor responsiveness in lymphoid malignancies. PLoS One. 2018; 13:e0197000. https://doi.org/10.1371/journal. pone.0197000. [ [PubMed]

137. Weinstein RS, Jilka RL, Almeida M, Roberson PK, Manolagas SC. Intermittent parathyroid hormone administration counteracts the adverse effects of glucocorticoids on osteoblast and osteocyte viability, bone formation, and strength in mice. Endocrinology. 2010; 151:2641-49. https:// doi.org/10.1210/en.2009-1488. [PubMed]

138. Yoshikawa N, Shimizu N, Uehara M, Oda A, Matsumiya R, Matsubara E, Kobayashi H, Hosono O, Kuribara-Souta A, Baba H, Nagamura F, Kiryu S, Tanaka H. The effects of bolus supplementation of branched-chain amino acids on skeletal muscle mass, strength, and function in patients with rheumatic disorders during glucocorticoid treatment. Mod Rheumatol. 2017; 27:508-17. https://doi.org/10.1080/1439 7595.2016.1213480. [PubMed]

139. Karnia MJ, Korewo D, Myślińska D, Ciepielewski ZM, Puchalska M, Konieczna-Wolska K, Kowalski K, Kaczor JJ. The Positive Impact of Vitamin D on GlucocorticoidDependent Skeletal Muscle Atrophy. Nutrients. 2021; 13:936. https://doi.org/10.3390/nu13030936. [PubMed]

140. Kinoshita H, Miyakoshi N, Kasukawa Y, Sakai S, Shiraishi A, Segawa T, Ohuchi K, Fujii M, Sato C, Shimada Y. Effects of eldecalcitol on bone and skeletal muscles in glucocorticoid-treated rats. J Bone Miner Metab. 2016;
34:171-78. https://doi.org/10.1007/s00774-015-0664-4. [PubMed]

141. Miyakoshi N, Sasaki H, Kasukawa Y, Kamo K, Shimada Y. Effects of a vitamin D analog, alfacalcidol, on bone and skeletal muscle in glucocorticoid-treated rats. Biomed Res. 2010; 31:329-36. https://doi.org/10.2220/biomedres.31.329. [PubMed]

142. Slominski A, Zjawiony J, Wortsman J, Semak I, Stewart J, Pisarchik A, Sweatman T, Marcos J, Dunbar C, Tuckey RC. A novel pathway for sequential transformation of 7-dehydrocholesterol and expression of the P450scc system in mammalian skin. Eur J Biochem. 2004; 271:4178-88. https://doi.org/10.1111/j.1432-1033.2004.04356.x. [PubMed]

143. Slominski AT, Kim TK, Chen J, Nguyen MN, Li W, Yates CR, Sweatman T, Janjetovic Z, Tuckey RC. Cytochrome P450scc-dependent metabolism of 7-dehydrocholesterol in placenta and epidermal keratinocytes. Int $\mathrm{J}$ Biochem Cell Biol. 2012; 44:2003-18. https://doi.org/10.1016/j. biocel.2012.07.027. [PubMed]

144. Slominski AT, Kim TK, Li W, Postlethwaite A, Tieu EW, Tang EKY, Tuckey RC. Detection of novel CYP11A1derived secosteroids in the human epidermis and serum and pig adrenal gland. Sci Rep. 2015; 5:14875. https://doi. org/10.1038/srep14875. [PubMed]

145. Maubec E, Laouénan C, Deschamps L, Nguyen VT, ScheerSenyarich I, Wackenheim-Jacobs AC, Steff M, Duhamel S, Tubiana S, Brahimi N, Leclerc-Mercier S, Crickx B, Perret C, et al. Topical Mineralocorticoid Receptor Blockade Limits Glucocorticoid-Induced Epidermal Atrophy in Human Skin. J Invest Dermatol. 2015; 135:1781-89. https://doi.org/10.1038/jid.2015.44. [PubMed]

146. Choi KJ, Na YJ, Jung WH, Park SB, Kang S, Nam HJ, Ahn JH, Kim KY. Protective effect of a novel selective $11 \beta$-HSD1 inhibitor on eye ischemia-reperfusion induced glaucoma. Biochem Pharmacol. 2019; 169:113632. https:// doi.org/10.1016/j.bcp.2019.113632. [PubMed]

147. Puigoriol-Illamola D, Leiva R, Vázquez-Carrera $M$, Vázquez S, Griñán-Ferré C, Pallàs M. 11 $\beta$-HSD1 Inhibition Rescues SAMP8 Cognitive Impairment Induced by Metabolic Stress. Mol Neurobiol. 2020; 57:551-65. https:// doi.org/10.1007/s12035-019-01708-4. [PubMed]

148. Mancha-Ramirez AM, Yang X, Liang H, Junco J, Lee KP, Bovio SF, Espinoza M, Wool J, Slaga A, Glade DC, Hanes M, Malik G, Kim DJ, et al. Harnessing the gatekeepers of glucocorticoids for chemoprevention of non-melanoma skin cancer. Mol Carcinog. 2019; 58:102-12. https://doi. org/10.1002/mc.22912. [PubMed]

149. Hardy RS, Botfield H, Markey K, Mitchell JL, Alimajstorovic Z, Westgate CSJ, Sagmeister M, Fairclough RJ, Ottridge RS, Yiangou A, Storbeck KH, Taylor AE, Gilligan LC, et al. 11ßHSD1 Inhibition with AZD4017 Improves Lipid Profiles and Lean Muscle Mass in Idiopathic Intracranial Hypertension. J Clin Endocrinol Metab. 2021; 106:174-87. https://doi.org/10.1210/clinem/ dgaa766. [PubMed] 
150. Lesovaya EA, Savinkova AV, Morozova OV, Lylova ES, Zhidkova EM, Kulikov EP, Kirsanov KI, Klopot A, Baida G, Yakubovskaya MG, Gordon LI, Readhead B, Dudley JT, Budunova I. A Novel Approach to Safer Glucocorticoid Receptor-Targeted Anti-lymphoma Therapy via REDD1 (Regulated in Development and DNA Damage 1) Inhibition. Mol Cancer Ther. 2020; 19:1898-908. https:// doi.org/10.1158/1535-7163.MCT-19-1111. [PubMed]

151. Lipina C, Hundal HS. Is REDD1 a Metabolic Éminence Grise? Trends Endocrinol Metab. 2016; 27:868-80. https:// doi.org/10.1016/j.tem.2016.08.005. [ubMed]

152. Brugarolas J, Lei K, Hurley RL, Manning BD, Reiling JH, Hafen E, Witters LA, Ellisen LW, Kaelin WG Jr. Regulation of mTOR function in response to hypoxia by REDD1 and the TSC1/TSC2 tumor suppressor complex. Genes Dev. 2004; 18:2893-904. https://doi.org/10.1101/gad.1256804. [PubMed]

153. Shimizu N, Yoshikawa N, Ito N, Maruyama T, Suzuki Y, Takeda S, Nakae J, Tagata Y, Nishitani S, Takehana K, Sano M, Fukuda K, Suematsu M, et al. Crosstalk between glucocorticoid receptor and nutritional sensor mTOR in skeletal muscle. Cell Metab. 2011; 13:170-82. https://doi. org/10.1016/j.cmet.2011.01.001. [PubMed]
154. Lesovaya E, Agarwal S, Readhead B, Vinokour E, Baida G, Bhalla P, Kirsanov K, Yakubovskaya M, Platanias LC, Dudley JT, Budunova I. Rapamycin Modulates Glucocorticoid Receptor Function, Blocks Atrophogene REDD1, and Protects Skin from Steroid Atrophy. J Invest Dermatol. 2018; 138:1935-44. https://doi.org/10.1016/j. jid.2018.02.045. [PubMed]

155. Wei M, Gao Y, Lu B, Jiao Y, Liu X, Cui B, Hu S, Sun L, Mao S, Dong J, Yan L, Chen Z, Zhao Y. FKBP51 regulates decidualization through Ser473 dephosphorylation of AKT. Reproduction. 2018; 155:283-95. https://doi.org/10.1530/ REP-17-0625. [PubMed]

156. Dennis MD, Coleman CS, Berg A, Jefferson LS, Kimball SR. REDD1 enhances protein phosphatase 2A-mediated dephosphorylation of Akt to repress mTORC1 signaling. Sci Signal. 2014; 7:ra68. https://doi.org/10.1126/ scisignal.2005103. [PubMed]

157. Agarwal S, Mirzoeva S, Readhead B, Dudley JT, Budunova I. PI3K inhibitors protect against glucocorticoid-induced skin atrophy. EBioMedicine. 2019; 41:526-37. https://doi. org/10.1016/j.ebiom.2019.01.055. [PubMed] 